\title{
The Proper Use of Technologies as a Digital Citizenship Indicator: Undergraduate English Language Students at Al-Hussein Bin Talal University
}

\author{
Mustafa Jwaifell ${ }^{1, *}$ \\ ${ }^{1}$ Department of Curriculum and Instruction, Faculty of Educational Sciences, Al-Hussein Bin Talal University, Ma'an, \\ Hashemite Kingdom of Jordan \\ *Correspondence: Department of Curriculum and Instruction, Faculty of Educational Sciences, Al-Hussein Bin Talal \\ University, PO box 20, Ma'an, Hashemite Kingdom of Jordan. Tel: 9-626-775-620-480 E-mail: jwaifell@hotmail.com
}

Received: May 17, 2018

Accepted: June 11, $2018 \quad$ Online Published: June 22, 2018

doi:10.5430/wje.v8n3p86

URL: https://doi.org/10.5430/wje.v8n3p86

\begin{abstract}
The paper investigates the technology usage as a digital citizenship indicator among undergraduate English language students at Al-Hussein Bin Talal University (AHU) in Jordan. Digital citizenship with its nine elements: Etiquette, Communication, Education, Access, Commerce, Responsibility, Rights, Safety, and Security are connected to all life aspects. It is hard to ignore the increasing misuse phenomenon of the emerging technologies. This paper shed the light on how the students within their university campus use technologies in a citizenship manner. A measurement tool worked as a test to reveal students technology usage as an indicator of their digital citizenship. Results of the study revealed that students do not properly use technologies as a digital citizenship indicator. The study included recommendations to overcome technology usage within university campus.
\end{abstract}

Keywords: introduction digital citizenship, technologies, Jordanian university students, English language students

\section{Introduction}

Technology is widely used in the Arab world among all levels of school and university students. Yet, there isn't a realevidence about technology misuse within university students, which may lead to a major problem. Most students in Jordanian universities own and use technology such as computers and smart mobile phones. Thus, they can use those technologies appropriately to access on-line resources for information which enhances their learning process. However, it requires full understanding of technology and how to use it. In Jordan for instance, school as well as university curricula do not provide students with full awareness of how to use technology.

\section{Backgrounf of the Study}

There is significant increasing evidence of emerging technologies misuse all over the world as the popular press has pointed. Many websites intimidate or threaten youth in general and students in particular, through providing them with free online access to download pornographic materials or right-preserved materials such as music, plagiarize information from websites through 'copy/paste' options, and the most important thing is using mobile phones during university time or even inside lectures without any instructor guidance. Furthermore, they can even download illegal software without any software protection which may lead to hacking accounts. The National Cyber Security Alliance (2003) states that $67 \%$ of broadband users do not have properly installed and securely configured firewalls.

Digital citizenship encompasses a wide range of behaviors and usages with varying degrees of risk and possible uncountable dangerous consequences. If educational policy-makers do not address enlightening educators and students to establish a digital culture, it will be so hard to overcome problems that will emerge.

\section{Digital Citizenship}

Digital citizenship can be defined as "the norms of behavior for technology use" (Ribble \&Bailey, 2006. 28). Digital citizenship consists of nine elements (ISTE, 2011): digital access, commerce, communication, literacy, etiquette, law, 
rights and responsibilities, health and wellness, and security.

Element 1: Digital Access: This can be defined as the full electronic participation in society; in that a large number of people can communicate with each other. Here, 'social networks' is a very good example of interactive communicational technology.

Element 2: Digital Commerce: defined as the electronic buying and selling goods. Nowadays, many people including youths sell and buy through Internet websites, especially in Jordan where buying via Facebook became very popular. So learning how to become an intelligent consumer is an important indicator of good citizenship.

Element 3: Digital Communication: exchanging knowledge and information electronically. This factor is very important especially during the Arab Spring era, where sharing false information may misguide youths and lead tham to interact with those who have a private agenda that does not serve humanity, such as terrorist organizations who might tend to communicate with others for abuse purposes.

Element 4: Digital Literacy: knowing about technology and its use. For example, Jordan started to educate youths about new technology and how to use it as a source of information. Bani Abdelrahman, Jwaifell \& El-Subhieen, (2014) investigated information literacy among the students in Jordan. The study shows that information skills are not mastered by AHU students.

Element 5: Digital Etiquette: the main concern of this aspect is electronic standards of conduct or procedure. Students should learn that it is not how others use technology but rather how to use it in an appropriate manner. Studies in Jordan investigated the use of technology among university students (Jwaifell, M., Al-Shalabi, H., Andraws, S., Awajan, A., \& Alrabea, A. 2013; Swidan, A., Al-Shalabi, H., Jwaifell, M., Awajan, A., \& Alrabea, A. 2013; Nassar, I. A, Hayajneh, J. A, \& Almsafir, M. K. H. 2013; Al Doghmi, A., Al-Shalabi, H., Jwaifell, M., Andraws, S., Awajan, A., \& Alrabea, A. I. (2013).

Element 6: Digital Law: it refers to the electronic responsibility for actions and deeds. Students should be aware of legal and illegal use of information available on the Internet since technology fascilitated to the process of uploading, downloading, locating and accessing information. Therefore, it is very important to distinguish between what is legal and what is not in addition to the intellectual property and authoring ethics.

Element 7: Digital Rights and Responsibilities: rights and responsibilities are the requirements and freedoms extended to all users in digital world. Digital societies have their own rules, and it is expected that any member should be committed to those rules and ethics and accept group policies, even the protection that groups provide.

Element 8: Digital Health and Wellness: it is the physical and psychological well-being within digital technology. Internet addiction is one of the psychological dangers students may face, in addition to body injury such as neck's vertebra and carpal tunnel syndrome.

Element 9: Digital Security: software and hardware protections. Violating personal data by viruses should be considered as a digital crime which is an essential aspect of this element. Therefore, students should learn how to protect their data, files and any software; or they will be under the threaten of hackers.

Ribble \&Bailey (2006) resembled nine elements of digital citizenship in a form of a quiz including nine questions and statements with four multiple choices. The nine elements were: Digital Etiquette (Manners), Digital Communication (Messages), Digital Education (Learning), Digital Access (inclusion), Digital Commerce (Business), Digital Responsibility (Trust), Digital Rights (Privileges), Digital Safety (Protection), and Digital Security (Self-Protection). Items of the quiz are formed as questions or statements with one right answer as shown in Taple1 after modifying items for university students: 
Table 1. Digital Citizenship Quiz

\begin{tabular}{|c|c|c|}
\hline Elements & Questions and Statements & Answers \\
\hline $\begin{array}{l}\text { Digital Etiquette } \\
\text { (Manners) }\end{array}$ & $\begin{array}{l}\text { Having your cell phone turned on } \\
\text { during university hours is }\end{array}$ & hers \\
\hline $\begin{array}{l}\text { Digital Communication } \\
\text { (Messages) }\end{array}$ & $\begin{array}{l}\text { How many people should you have in } \\
\text { your messenger Buddy List? }\end{array}$ & d family \\
\hline $\begin{array}{l}\text { Digital Education } \\
\text { (Learning) }\end{array}$ & $\begin{array}{l}\text { When learning about technology in } \\
\text { university, it is important for you to } \\
\text { know }\end{array}$ & $\begin{array}{l}\text { fferent technologies are and } \\
\text { y are used }\end{array}$ \\
\hline $\begin{array}{l}\text { Digital Access } \\
\text { (Inclusion) }\end{array}$ & Students with disabilities & $\begin{array}{l}\text { should have the same opportunities } \\
\text { as others to use technology }\end{array}$ \\
\hline $\begin{array}{l}\text { Digital Commerce } \\
\text { (Business) }\end{array}$ & $\begin{array}{l}\text { If your parents allow you to buy things } \\
\text { on the Internet, you should protect } \\
\text { yourself by }\end{array}$ & $\begin{array}{l}\text { checking to see if the site is safe and } \\
\text { secure }\end{array}$ \\
\hline $\begin{array}{l}\text { Digital Responsibility } \\
\text { (Trust) }\end{array}$ & $\begin{array}{l}\text { When using graphics and text from the } \\
\text { Internet, you should }\end{array}$ & $\begin{array}{l}\text { give credit to the author of the } \\
\text { information in the project }\end{array}$ \\
\hline $\begin{array}{l}\text { Digital Rights } \\
\text { (Privileges) }\end{array}$ & When using technology, you should & $\begin{array}{l}\text { ask teachers and parents about what } \\
\text { can be done }\end{array}$ \\
\hline $\begin{array}{l}\text { Digital Safety } \\
\text { (Protection) }\end{array}$ & $\begin{array}{l}\text { How you work with technology (e.g., } \\
\text { sitting, laying, and stooping at the desk, } \\
\text { floor, or sofa): }\end{array}$ & $\begin{array}{l}\text { is important because poor posture } \\
\text { can cause physical problems later in } \\
\text { life }\end{array}$ \\
\hline $\begin{array}{l}\text { Digital Security } \\
\text { (Self-Protection) }\end{array}$ & $\begin{array}{l}\text { When dealing with people online, } \\
\text { giving personal information is }\end{array}$ & $\begin{array}{l}\text { never a good idea, no matter the } \\
\text { reason }\end{array}$ \\
\hline
\end{tabular}

\section{Digital Citizenship Awareness}

Teachers at any level and parents can discuss the nine elements of digital citizenship with students/children to direct their perception and usage of technology towards using and practicing it appropriately. Ribble (2009) suggested a four-stage technology learning framework for teaching digital citizenship as to be reflected on its usage: Raising Awareness by engaging students to become technologically literate and understand the problems of misusing their knowledge of hardware and software so that they become more aware of the appropriate use, Guided Practice which follows Awareness activities needs educators to take their part in providing students with situations based on using technology under the educators' guidance which should focus on the proper use of technology, Modeling and Demonstration related to teachers planning how to spend time while using technology appropriately whether at school, home or in society, and Feedback and Analysis which refers to the school role in providing time and place for both teachers and students for discussing their use of technology in order to assure shifting the proper use to a higher level.

\section{Related Studies}

In the current time, a few research studies have been conducted to investigate the use of technologies as a digital citizenship indicator. To our best knowledge, there is no specific study in Jordan that has been conducted to investigate the students' digital citizenship in a form of a test survey. One study was conducted in Jordan aimed to identify the degree of embedding digital citizenship concepts within national and civic educational textbooks. The study sample consisted of (43) teachers. The study adopted structured interviews and content analysis of all collected surveyed data. The results revealed an absence of the use of the term digital citizenship in all national and civic textbooks, and they were free of any occurrence of (63) concepts. The results also revealed that of the (56) concepts, only (36) appeared in the textbooks of national education of the eighth-grade alone, and the number of occurrences of (33) concepts were (3) or less. The concepts of digital ayes and digital literacy were the axes in all textbooks of national and civic education; only (5) of the (9) ayes appeared in the textbook of national and civic education of eighth-grade. Results also revealed the absence of teachers' knowledge of national and civic education of the ayes and concepts of digital citizenship. 
Meanwhile, there are a few studies globally conducted: d'Haenens, Koeman \& Saeys (2007) investigated the digital citizenship among ethnic minority youths in Netherlands and Flanders. The study sample consisted of six different ethnics: Flemish Turks, Dutch Turk, Flemish Moroccans, Native Flemish and Native Dutch. The tool of the study was a questionnaire distributed for gathering data. The research dealt with five distinguished types of digital citizens: e-communicating, e-democratic, e-surfing, e-working and e-consuming. The study concluded that ethnics could emerge different uses of ICT, like gender for instance; as Moroccan girls communicate only with their relatives and other ethnics from the same gender. Ethnic minority youths are more interested in the political sense than native youths. In e-cultural citizen, young people have little interest in highbrow art forms. It can be concluded that using ICT may lead to bridge the gap between cultures rapidly and can work as an indicator for being citizens in a form of e-citizenship.

Social network sites can be considered as the most suitable environment to establish a digital community; therefore it may provide a rich field for studying digital citizenship. Lenhart, Madden, Smith, Purcell, Zickuhr \& Raninie (2011) explored how American teens navigate the new world of digital citizenship. They considered distinguishing between good and bad while navigating social network sites as the indicator of digital citizenship. The finding of the study revealed that teens witnessed cruelty, negative outcomes and harassment.

Schools are responsible of preparing students for this digital era. Dillinger (2015) explored in her thesis resources and standards available to educators to help implement digital citizenship into the curriculum and how to enhance classroom lessons with digital citizenship skills where technology is used. The results of her study demonstrated the need to incorporate digital citizenship skills into school lessons in order to teach students independent and responsible online behavior.

Tawalbe (2017) identified the degree of embedding digital citizenship concepts in national and civic educational textbooks, and the familiarity of teachers with digital citizenship concepts. The sample of the study consisted of (43) teachers of national and civic education in Jordan, and all the textbooks of national and civic education for the academic year 2016/2017. The results Tawalbe's study revealed showed an absence of the use of the term digital citizenship in all national and civic textbooks, and they were free of any occurrence of (63) concepts. Results also revealed the absence of the teachers' knowledge of national and civic education of the ayes and concepts of digital citizenship.

\section{Purpose of the Study}

This study was conducted under the claim that better technologies usage works as an indicator of digital citizinship. Therefore, this study aimed to investigate the technology usage as a digital citizenship indicator among undergraduate English language students at Al-Hussein Bin Talal University (AHU) in Jordan, by answering the following questions:

Q1: Do undergraduate English language students at AHU in Jordan use technologies properly as a digital citizenship indicator?

Q2: Do undergraduate English language students at AHU in Jordan differ in using technologies properly as a digital citizenship indicator according to their gender?

Q3: Do undergraduate English language students at AHU in Jordan differ in using technologies properly as a digital citizenship indicator according to their year of study?

\section{Methodology}

The primary purpose of this study was to quantitatively examine students' proper use of technology as a digital citizenship indicator, therefore, the study design is descriptive, thus the researcher conducted the survey through a measurement tool as a means for collecting data on the proper use of technology as a digital citizenship.

\subsection{Setting and Sample}

The sample of this study consisted of all (310) undergraduate English language students at AHU in Jordan, where (25) of them are dealt with for calculating reliability and only $(263=85 \%)$ of the population can be reached as shown in Table2: 
Table 2. The Participants of the Study

\begin{tabular}{llllll}
\hline Gender & First Year & Second Year & Third Year & Fourth Year & Total \\
\hline Male & 14 & 18 & 13 & 30 & 77 \\
Female & 14 & 29 & 54 & 89 & 186 \\
Total & 30 & 47 & 67 & 119 & 263 \\
\hline
\end{tabular}

The researcher's main concern is committed to measure technology usage as a digital citizenship indicator among undergraduate English language students at AHU in Jordan in order to understand the whole picture of their usage of technologies as a digital citizenship indicator and give recommendations to the administration of AHU in Jordan and the academic staff for better understanding when planning to the use of technologies and the Internet.

\subsection{The Measurement Tool}

The study modified the items of instruments based on Ribble \& Bailey (2006). While analyzing the items content, it appears to the researcher and the six referees who validated the quiz that those items do not have any cultural biases and are commonly applicable to undergraduate English language students at AHU in Jordan within a Middle Eastern context, while the quiz items dedicated to all K-12 levels students, the referees pointed that the quiz is suitable for University students after modification (see table1). The modified quiz reliability was calculated by (25) student participants and were drawn from the population itself, where Pearson Correlation $=0.855$ which is significant at the 0.01 level.

\section{Findings and Discussion}

The Analyses of the resulting data were performed using descriptive statistics. Descriptive measures including means, standard deviations and frequencies of Right Answer (R.A) and Wrong Answer (W.A) for proper use of technologies as a digital citizenship indicator were used to answer the questions of the study. These descriptive statistical measures were also tabulated and reported for classifying variables (Gender, Year) to determine students' proper use of technologies as a digital citizenship indicator, as shown in Table3:

Table 3. Answers of the Quiz

\begin{tabular}{|c|c|c|c|c|c|c|c|c|c|c|c|c|c|c|c|c|}
\hline \multirow{3}{*}{ Elements } & \multicolumn{4}{|c|}{ Gender } & \multicolumn{8}{|c|}{ Year of study } & \multirow{2}{*}{\multicolumn{2}{|c|}{ Total }} & \multirow{2}{*}{\multicolumn{2}{|c|}{$\%$}} \\
\hline & \multicolumn{2}{|l|}{ Male } & \multicolumn{2}{|c|}{ Female } & \multicolumn{2}{|c|}{ First year } & \multicolumn{2}{|c|}{$\begin{array}{l}\text { Second } \\
\text { year }\end{array}$} & \multicolumn{2}{|c|}{ Third year } & \multicolumn{2}{|c|}{ Fourth year } & & & & \\
\hline & R.A & W.A & R.A & W.A & R.A & W.A & R.A & W.A & R.A & W.A & R.A & W.A & R.A & W.A & R.A & W.A \\
\hline Digital Etiquette & 22 & 55 & 58 & 138 & 14 & 16 & 18 & 29 & 20 & 47 & 28 & 91 & 80 & 183 & 30 & 70 \\
\hline $\begin{array}{l}\text { Digital } \\
\text { Communication }\end{array}$ & 45 & 32 & 126 & 60 & 10 & 20 & 35 & 12 & 48 & 19 & 78 & 41 & 171 & 92 & 65 & 35 \\
\hline Digital Education & 34 & 43 & 102 & 84 & 9 & 21 & 23 & 24 & 44 & 23 & 60 & 59 & 136 & 127 & 52 & 48 \\
\hline Digital Access & 35 & 42 & 72 & 114 & 11 & 19 & 22 & 25 & 32 & 35 & 42 & 77 & 107 & 156 & 41 & 59 \\
\hline Digital Commerce & 42 & 35 & 102 & 84 & 17 & 13 & 22 & 25 & 44 & 23 & 61 & 58 & 144 & 119 & 55 & 45 \\
\hline Digital Responsibility & 18 & 59 & 50 & 136 & 4 & 26 & 17 & 30 & 17 & 50 & 30 & 89 & 68 & 195 & 26 & 74 \\
\hline Digital Rights & 29 & 48 & 82 & 104 & 13 & 17 & 16 & 31 & 34 & 33 & 48 & 71 & 111 & 152 & 42 & 58 \\
\hline Digital Safety & 7 & 70 & 28 & 158 & 1 & 29 & 7 & 40 & 7 & 60 & 20 & 99 & 35 & 228 & 13 & 87 \\
\hline Digital Security & 24 & 53 & 86 & 100 & 8 & 22 & 21 & 26 & 32 & 35 & 49 & 70 & 110 & 153 & 42 & 58 \\
\hline Total & 256 & 437 & 706 & 968 & 87 & 183 & 181 & 242 & 278 & 325 & 416 & 655 & 962 & 1405 & 41 & 59 \\
\hline
\end{tabular}

Taple3 showed the answers of AHU students to the quiz questions and statements. It appears that Digital Safety is the most improper use of technologies as a digital citizenship indicator where only (35) students out of (263) choose the right answer with (13\%), and this result indicates the poor knowledge of how to use technologies in the university campus among students. While (171) students out of (263) choose the right answer with (65\%) for Digital 
Communication which can be referred to cultural bias and religion of community those students belong to. Those results indicated that:

1. Students have to be more educated regarding the manner of using digital devices within the university campus, where only $30 \%$ of them know and practice digital etiquette.

2. Digital communication was used in a prober way; (65\%) of the students confirmed the right answer: communicating with close friends and family members. In the Arab culture, parents monitor their children's devices when used to communicate with others, in addition to the way they reinforce the religious aspect in their children.

3. Digital education with (52\%) of right answer about how to choose the right technology for learning showed how students were divided between knowing how to choose the right technologies to be used or not, which indicates a greater need for educating students about how to choose the right technologies to use for learning within the university.

4. All the other elements: digital access, commerce, responsibility, rights, safety and security are not known very well for most of the students, which reveals the lack of training and supervision. Arab people usually deal with trust in their ordinary life, they were not raised to mistrust, and this may explaine their wrong answers.

Q1: Do undergraduate English language students at AHU in Jordan use technologies properly as a digital citizenship indicator?

The total score of students' answers were tabulated according to each element of digital citizenship as shown in Figger 1:

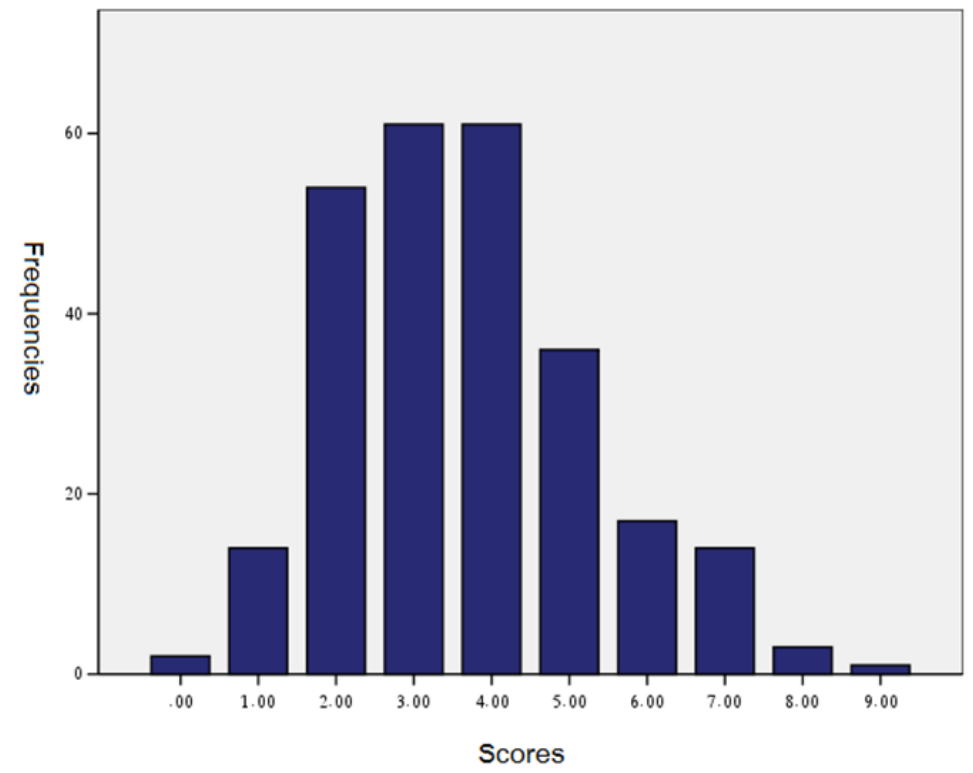

Figger 1. Quiz Students Scores

It appears from Figger1 that students scores distributed normally, where the carve goes to the left side, this means that most of the students didn't answer (50\%) of the Quiz, Mean of the total student was (3.66) with a standard deviation (1.64), which is less than the score $(9 / 2=4.5=50 \%)$. One sample t-test with ( $\mathrm{df}=262)$ was used to determine the proper use of technologies as a digital citizenship indicator of AHU students at the crucial score (4.5).

One sample t-test revealed significant differences at $\alpha \leq 0.05$ (where $t=8.313$ ) between the means of proper use of technologies as a digital citizenship indicator the crucial score (4.5). Thus, undergraduate English language students at AHU in Jordan do not use technology properly as a digital citizenship indicator. That means, students do not practice the digital citizenship within the campus of their university.

Q2: Do undergraduate English language students at AHU in Jordan differ in using technologies properly as a digital citizenship indicator according to their gender?

To answer the second question, frequencies were calculated and tabulated as shown in Table4, the Chi Square was 
used to examine the distributions of males/females R.As and W.As as shown in the following table:

Table 3. Male/Female Answers and Chi Square Results

\begin{tabular}{|c|c|c|c|c|c|c|c|}
\hline \multirow{3}{*}{ Elements } & \multirow{3}{*}{ No } & \multicolumn{4}{|c|}{ Gender } & \multirow{3}{*}{ Chi Square } & \multirow{3}{*}{$\begin{array}{l}\text { Sig } \\
\text { (2-sided) }\end{array}$} \\
\hline & & \multicolumn{2}{|l|}{ Male } & \multicolumn{2}{|c|}{ Female } & & \\
\hline & & R.A & W.A & R.A & W.A & & \\
\hline \multirow[t]{2}{*}{ Digital Etiquette } & Observed & 22 & 55 & 58 & 128 & 0.675 & 0.769 \\
\hline & Expected & 23.4 & 53.6 & 56.6 & 129.4 & & \\
\hline \multirow[t]{2}{*}{ Digital Communication } & Observed & 45 & 32 & 126 & 60 & 2.071 & 0.158 \\
\hline & Expected & 50.1 & 26.9 & 120.9 & 65.1 & & \\
\hline \multirow[t]{2}{*}{ Digital Education } & Observed & 34 & 43 & 102 & 84 & 2.489 & 0.136 \\
\hline & Expected & 39.8 & 37.2 & 96.2 & 89.8 & & \\
\hline \multirow[t]{2}{*}{ Digital Access } & Observed & 35 & 42 & 72 & 114 & 1.027 & 0.336 \\
\hline & Expected & 31.3 & 45.7 & 75.7 & 110.3 & & \\
\hline \multirow[t]{2}{*}{ Digital Commerce } & Observed & 42 & 35 & 102 & 84 & 0.002 & 1.00 \\
\hline & Expected & 42.2 & 34.8 & 101.8 & 84.2 & & \\
\hline \multirow[t]{2}{*}{ Digital Responsibility } & Observed & 18 & 59 & 50 & 136 & 0.349 & 0.643 \\
\hline & Expected & 19.9 & 57.1 & 48.1 & 137.9 & & \\
\hline \multirow[t]{2}{*}{ Digital Rights } & Observed & 29 & 48 & 82 & 104 & 0.921 & 0.411 \\
\hline & Expected & 32.5 & 44.5 & 78.5 & 106.5 & & \\
\hline \multirow[t]{2}{*}{ Digital Safety } & Observed & 7 & 70 & 28 & 158 & 1.678 & 0.234 \\
\hline & Expected & 10.2 & 66.8 & 24.8 & 161.2 & & \\
\hline \multirow[t]{2}{*}{ Digital Security } & Observed & 24 & 53 & 86 & 100 & 5.081 & 0.028 \\
\hline & Expected & 32.2 & 44.8 & 77.8 & 108.2 & & \\
\hline \multirow[t]{2}{*}{ Total } & Observed & 256 & 437 & 706 & 968 & 5.565 & 0.019 \\
\hline & Expected & 281.7 & 411.3 & 680.3 & 993.7 & & \\
\hline
\end{tabular}

Results of Chi Square showed no statistical significance differences between males and females' distributions for the proper use of technologies as a digital citizenship indicator among undergraduate English language students at AHU in Jordan according to their gender, except for the Digital Security element and total of elements. Femals showed more frequency at the observed R.As than the expected frequency in both elements while Males showed less obsereved frequency than the expected R.As.

When using Two sample t-test with $(\mathrm{df}=261, \mathrm{t}=2.13)$ at $\alpha \leq 0.05$ significance differences between Females and Males' scores for the benefit of Females with $\mathrm{M}=3.80, \mathrm{sd}=1.68$ while with Males' $\mathrm{M}=3.32$, $\mathrm{sd}=1.51$, thus, undergraduate English language students at AHU in Jordan differ in using technology properly as a digital citizenship indicator according to their gender for the benefit of Females students.

Q3: Do undergraduate English language students at AHU in Jordan differ in using technologies properly as a digital citizenship indicator according to their year of study?

To answer the third question, means and standard deviations were calculated to examine the differences of technologies proper use as a digital citizenship indicator according to the study year as shown in Table 6: 
Table 6. Means an Standard Deviations According to Year of Study

\begin{tabular}{llll}
\hline Year of Study & $\mathrm{N}$ & Mean & sd \\
\hline First Year & 30 & 2.90 & 2.01 \\
Second Year & 47 & 3.85 & 1.61 \\
Third Year & 67 & 4.15 & 1.81 \\
Fourth Year & 119 & 3.50 & 1.35 \\
Total & 263 & 3.66 & 1.64 \\
\hline
\end{tabular}

Table 6 shows observable differences between the means of proper use of technologies as a digital citizenship indicator according to the study year. One-way ANOVA was conducted to examine the observed differences as shown in Table 7:

Table 7. One Way ANOVA

\begin{tabular}{llllll}
\hline Source of Variance & Sum of Squares & df & Mean Square & F & Sig. \\
\hline Between Groups & 38.289 & 3 & 12.763 & 4.942 & .002 \\
Within Groups & 668.913 & 259 & 2.583 & & \\
Total & 707.202 & 262 & & & \\
\hline
\end{tabular}

Results of ANOVA revealed significant differences at $\alpha \leq 0.05$ between the means of proper use of technologies as a digital citizenship indicator according to the study year for the benefit of higher mean. Scheffe's Post multiple comparisons was conducted to assure those differences as shown in Table 8:

Table 8. Results of Scheffe's Multiple Comparisons One Way ANOVA

\begin{tabular}{lllll}
\hline Year of Study & First Year & Second Year & Third Year & Fourt Year \\
\hline First Year & - & -0.95106 & $-1.124925^{*}$ & -0.59580 \\
Second Year & 0.95106 & - & -0.29819 & 0.35527 \\
Third Year & $1.124925^{*}$ & 0.29819 & - & 0.65346 \\
Fourth Year & 0.59580 & -0.35527 & -0.65346 & - \\
\hline
\end{tabular}

* The mean difference is significant at the .05 level.

Post comparisons showed: Students in Third Year with the Mean=4.15 and $\mathrm{sd}=1.81$ are statistically higher than students means in First Year Mean=2.90 and sd=2.01.

These results can be justified for the low experience of first-year students. The more students interact with the university system, they gradually beome aware of digital citizenship elements. But when having a look at forth-year students, they showed less digital citizenship which can be referred to the impact of the graduate personality., I touched this fact when I had an experience among university students.

\section{Conclusion}

The study revealed that undergraduate English language students at Al-Hussein Bin Talal University (AHU) in Jordan do not properly use technologies as a digital citizenship indicator. Technology is not new phenomenon to the Jordanian community. Young people have been using smart mobile phones and computers for more than two decades, but it seems that policy makers in both ministries of education and higher education rely on parents more than curricula for raising awareness among students regarding the use of technology. Based on the study findings, it is significant to emerge efforts between both schools and universities to bridge the gap between technologies as a life tool and as an academic proper usage. Thus, this study sheds the light paying more attention to educating youths the concept of citizenship and how to use technologies appropriately. The study results can be read in relation to 
Tawalbe's (2017) findings which revealed that civic curriculum in Jordan lacks Digital Citizenship concepts. In other words, the study in hand complments Tawalbe's findings in that university students are expected to misunderstand or lack the notion of Digital Citizinship as a result of not having been prepared for it in school as a part of civic curriculum. Therefore, it is significant to improve school curricula in a way that develops the concept of Digital Citizinship among students at early stage of their education. This procedure prepares young people to be more technologically literate and adopt Digital Citizishipe notion in their daily life and later at university.

\section{References}

Al Doghmi, A., Al-Shalabi, H., Jwaifell, M., Andraws, S., Awajan, A., \& Alrabea, A. I. (2013). The academic use of social networks among university students in Jordan. International Journal of Computer Science Issues, 10(5), 134-141.

Bani Abdelrahman, Jwaifell \& El-Subhieen, (2014). Information Literacy: Study of Incoming First-year Undergraduates Students who major in English Language at Al- Hussein Bin Talal University. Journal of Education and Practice, 5(18), 152-167.

d'Haenens, L., Koeman, J., \& Saeys, F. (2007). Digital citizenship among ethnic minority youths in the Netherlands and Flanders. New Media \& Society, 9(2), 278. https://doi.org/10.1177/1461444807075013

Dillinger, A. (2015). DIGITAL CITIZENSHIP AND TODAY'S ONLINE STUDENT (Unpublished Theses) University of Central Missouri). http://centralspace.ucmo.edu/bitstream/handle/123456789/438/Dillinger_LIBRARY.pdf?sequence=1\&isAl lowed=y

ISTE (2011). Digital citizenship in schools. Retrieved from http://www.iste.org/docs/excerpts/DIGCI2-excerpt. Pdf

Jwaifell, M., Al-Shalabi, H., Andraws, S., Awajan, A., \& Alrabea, A. (2013). The intensity of social networks group use among the students of Jordanian universities. Global Journal of Computer Science and Technology Network, Web \& Security, 13(2), 1-8.

Lenhart A., Madden M., Smith A., Purcell K., Zickuhr K., \& Rainie L. (2015). Teens, Kindness and Cruelty on Social Network Sites. Washington, DC: Pew Internet and American Life Project; 2011. [2015-08-21]. Retrieved from http://www.pewinternet.org/2011/11/09/teens-kindness-and-cruelty-on-social-network-sites/

Nassar, I. A., Hayajneh, J. A., \& Almsafir, M. K. H. (2013). Relation between social network and da'wah to Islam: A case study on Jordanian students. International Journal on Islamic Applications in Computer Science and Technology, 1(1), 9-18.

National Cyber Security Alliance. (2003). Past and present danger: In-home study on broadband security among American consumers. Retrieved from http://www.staysafeonline.info/press/060403.pdf

Ribble, M., \& Bailey, G. (2006). Digital Citizenship at All Grade Levels. Learning \& Leading with Technology. ISTE. Retrieved April 12, 2017 from: http://www.whyville.net/press/L_LMar06Whyville.pdf

Swidan, A., Al-Shalabi, H., Jwaifell, M., Awajan, A., \& Alrabea, A. (2013). The intensity and the factors affecting the use of social network sites among the students of Jordanian universities. International Journal of Computer Science Issues, 10(1), 492-498.

Tawalbe, Hadi. (2017). Digital Citizenship in the National Civic Education Textbook: An Analytical Study. The Jordanian Journal of Educational Sciences, 13(3), 291-208. 